\title{
Ti-6Al-4V 合金の疲労挙動に及ぼすガス窒化の影慜*
}

\author{
戸 梶 惠 郎*1, 小川 武 史*1 \\ 柴 田 英 明*2, 神 谷 征 典*3
}

\section{The Effect of Gas Nitriding on Fatigue Behaviour of Ti-6Al-4V Alloy}

\author{
Keiro TOKAJI, Takeshi OGAWA, \\ Hideaki SHIBATA and Yukinori KAMIYA
}

\begin{abstract}
The fatigue behaviour of a gas-nitrided $\mathrm{Ti}-6 \mathrm{Al}-4 \mathrm{~V}$ alloy has been studied under rotating bending fatigue test. The results were compared to those of annealed materials on the basis of detailed observations on crack initiation, growth and fracture surfaces. Nitriding was performed using smooth specimens for $4 \mathrm{~h}$ and $15 \mathrm{~h}$ at $850^{\circ} \mathrm{C}$ in pure nitrogen gas, and the depths of the nitrided layer obtained were approximately $25 \mu \mathrm{m}$ and $65 \mu \mathrm{m}$, respectively. The fatigue lives of material nitrided for $4 \mathrm{~h}$ were shorter than those of annealed material, but the fatigue limit increased. On the other hand, fatigue strength was reduced by nitriding for $15 \mathrm{~h}$. It is concluded that the decrease in fatigue strength of nitrided materials is mainly attributed to inferior crack initiation resistance of the nitrided layer.
\end{abstract}

Key Words: Fatigue, Nonferrous Metal, Ti-6Al-4V Alloy, Gas Nitriding, Crack Initiation, Crack Growth

\section{1. 緒}

チタンおよびチタン合金は比強度と耐食性に優れて おり，それらの性質を活かして航空宇宙産業や化学工 業などを中心に利用されている．今後，さらに用途の 㹡大が期待される材料であるが, チタンは高い摩擦係 数と低い摩耗抵抗を示す(1)(2) ので, 摺動部や他金属と の接触の際に焼付きを生じやすい問題がある(3)(4).こ のような性質を改善するために，材料の表面を硬化さ せる種々の表面処理法が試みられている(2) (9). その中 で,ガス窒化は，材料の表面に比較的容易に硬質の窒 化首を生成させることができるので, 実用的手法とし て考虑されている(2) (6).この方法によって耐摩耗性は 著しく改善され(2)(4)(5)，実部材への応用が期待できる が, 同時にこのような表面改質材の疲労強度の評価を 行っておくことが必要である。

このような観点から, 著者らは, 先にガス窒化を施 した工業用純チタンについて回転曲げ疲労試験を行 い, 空化処理によって疲労強度が改善されることを報

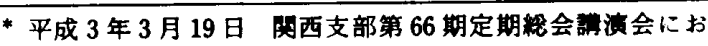
いて言演, 原稿受付 平成 3 年 2 月 15 日.

*1 正只, 岐阜大学工学部（6501-11 岐鼻市柳户 1-1).

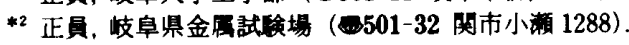

*3 学生員, 岐帛大学大学院.
}

告した(10). しかし,より実用的な立場からは、チタン 合金に関する同様の検討が必要と考えられる。

これまでに, Ti-6Al-4V 合金について, 而摩耗性改 善の観点から窒化処理の効果が検討されており, 付随 的に疲労強度も評価されている(2)(4)(7).これらの結果で は，窒化処理によって疲労強度が大幅に低下すること が示されているが, その機構の詳細な検討は行われて いない，また，最近，森田ら(11)によって疲労強度評価 を目的とした研究が行われているが, 疲労强度低下の 原因は必ずしも明らかにされていない。

そこで, 本研究では処理温度を $850^{\circ} \mathrm{C}$ 一定とし， 2 種類の処理時間でガス窒化を施した Ti-6Al-4V 合金 について, 回転曲げ疲労試験を実施し, き裂発生, き 裂形態，成長挙動および破面観察などの詳細な観察を 通じて, 疲労強度に及ぼす窒化処理の影響について検 討した。

\section{2. 材料およひ实験方法}

供試材は，素材直径 $16 \mathrm{~mm}$ の $\mathrm{Ti}-6 \mathrm{Al}-4 \mathrm{~V}$ 合金で, その化学成分を表 1 に示す. 試験片は, 直径 $8 \mathrm{~mm}$, 平 行部 $10 \mathrm{~mm}$ の平滑回転曲げ疲労試験片である。試験 片の平行部をエメリー紙で研磨後, 電解研磨を施し た.その後, 後述する熱処理および窒化処理を行い，実 
験に供した。なお，後述のSTA 材は熱処理後に加工 を行っている.

窒化処理は，試験片を入れた炉内を十分排気，高真 空としたのち処理温度まで加熱し，続いて市販の室素 ガス（純度 99.99\%）を注入し，炉内の圧力をほほ 0.13 $\mathrm{MPa}$ (1.3 気圧) に保った状態で所定の時間保持する ことにより行った。

窒化処理に際して，高い処理温度では深い窒化層が 得られるが，心部の結晶粒が著しく成長するので，疲 労強度にとっては好ましくない(10).そこで，処理温度 を $850^{\circ} \mathrm{C}$ 一定とし，処理時間を変えることによって窒 化首深さを制御した。実験に先立ち，4種類の処理時 間に対して, 後述する硬さ試験によって窒化首深さを 調べた．その結果を図 1 に示す，図から明らかなよう に，䇪化首は時間とともに樑くなるが，15～20 時間て ほほ一定となる傾向がある，同様の結果が, 純チタン について吉田ら(3)，また Ti-5Al-2.5Sn 合金について Mitchell ら(4)によっても得られている. 図1の結果を 参考に，処理時間を 4 時間と 15 時間の 2 種類とした。

本研究では，納入材に対して以下の処理をそれぞれ 施した材料を準備し, 疲労試験を行った。

（1） $950^{\circ} \mathrm{C} \cdot 1 \mathrm{~h}$ 水冷後, $540^{\circ} \mathrm{C} \cdot 4 \mathrm{~h}$ 空冷（溶体化処理 後, 時効) (STA 材)

(2) $850^{\circ} \mathrm{C} \cdot 4$ 時間窒化処理（4時間窒化材）

（3） $850^{\circ} \mathrm{C} \cdot 4$ 時間保持真空焼なまし（4 時間焼なま (材)

(4) $850^{\circ} \mathrm{C} \cdot 15$ 時間窒化処理（15 時間窒化材）

（5） $850^{\circ} \mathrm{C} \cdot 15$ 時間保持真空焼なまし（15 時間焼なま し材)

（1）は Ti-6Al-4V 合金の標準の熱処理のひとつで あり，基準の波労強度を得るためにまた $(3)$ おひび

表 1 材料の化学成分 (wt.\%)

\begin{tabular}{c|c|c|c|c|c|c|c|c}
\hline$H$ & 0 & N & C & Fe & Al & V & Y & Ti \\
\hline 0.0055 & 0.185 & 0.003 & 0.015 & 0.206 & 6.27 & 4.27 & $<0.001$ & bal. \\
\hline
\end{tabular}

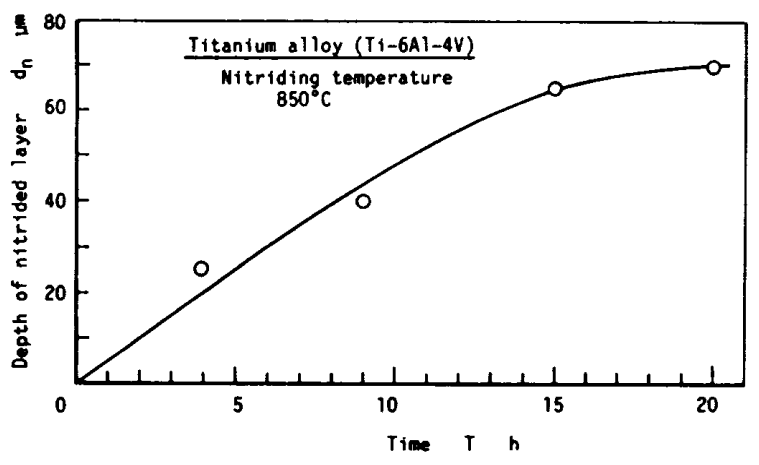

図 1 処理時間に伴う窒化届深さの変化
（5）の熱好理は窒化材と全く同一の熱展歴を与え，直 接窒化材と比較するために行ったものである。表 2 に 上記 5 種類の処理材の機械的性實を示す。結果は疲労 試験片と同一直径の JIS 2 号試験片によるものであ る、4 時間窒化材は，焼なまし材よりもやや強度が低 下するが, 15 時間窒化材は逆に上昇している。なお， 窒化材の心部の組織は，焼なまし材のそれと全く同様 $(\alpha+\beta$ 組織 $)$ であり，平均 $\alpha$ 粒径は 4 時間および 15 時

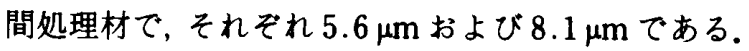

用いた試験機は, 容量 $98 \mathrm{~N} \cdot \mathrm{m}$ の小野式回転曲げ疲 労試験機であり, 室温大気中, 綝返し速度約 $57 \mathrm{~Hz}$ で 実験を行った。き裂発生および成長挙動の観察は, 所 定の繰返し数で試験機を一時停止し，アセチルセルロ ースフィルムを用いて試験片平行部のレプリカを採取 する方法によった、試験終了後, 画像処理装置を援用 して光学顕微鏡によりき裂長さを測定した。また，破 面観察には走查型電子影微鏡を用いた。

\section{3. 实鋫結 果}

3.1 窒化届の性状窒化材の外観は, 純チタン の場合 ${ }^{(30)}$ と同様に黄金色を呈しており,その色は処 理時間の長いほうが濃い. 図 2 に窒化材の組織写真を 示す，最表面の白い首は化合物層 (TiN 層) で，その 厚さは 4 時間窒化材で $2 \mu \mathrm{m}, 15$ 時間窒化材で $4 \mu \mathrm{m}$ 程度である。 $\mathrm{TiN}$ 層の下部には， $\alpha$ 相および $(\alpha+\beta)$ 相への窒素の固溶による固溶体硬化首が続くが, 組織 からはそれらの判別は困難である。

表 2 機械的性䨘

\begin{tabular}{|c|c|c|c|c|c|c|}
\hline \multicolumn{2}{|c|}{ Treatment } & $\begin{array}{l}0.27 \\
\text { proof } \\
\text { stress } \\
\mathrm{MPa}^{2}\end{array}$ & $\begin{array}{c}\text { Tensile } \\
\text { strength } \\
\sigma_{\beta} \\
\mathrm{MPa}_{\alpha}\end{array}$ & $\begin{array}{l}\text { Breaking } \\
\text { strength } \\
\text { on final } \\
\text { orea } \\
\end{array}$ & $\begin{array}{c}\text { Elongation } \\
\frac{1}{2}\end{array}$ & $\begin{array}{c}\text { Reduction } \\
\text { of area } \\
\frac{\psi}{\mathbf{Z}}\end{array}$ \\
\hline \multicolumn{2}{|c|}{ STA } & 1132 & 1238 & 1518 & 9 & 40 \\
\hline \multirow{2}{*}{$\begin{array}{c}850^{\circ} \mathrm{C} \\
4 \mathrm{~h}\end{array}$} & annealed & 927 & 971 & 1365 & 7 & 49 \\
\hline & nitrided & 890 & 943 & 1206 & 11 & 40 \\
\hline \multirow{2}{*}{$\begin{array}{l}850^{\circ} \mathrm{C} \\
15 \mathrm{~h}\end{array}$} & annesled & 900 & 950 & 1320 & 7 & 48 \\
\hline & nitrided & 925 & 974 & 1338 & 13 & 45 \\
\hline
\end{tabular}

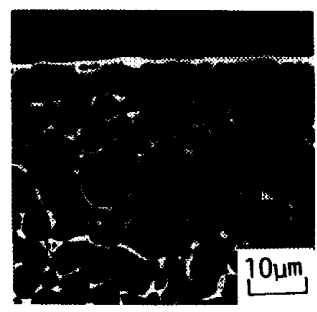

(a) 4 時間窒化材

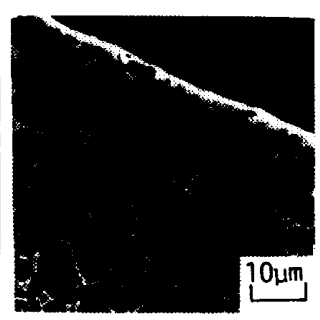

（b） 15 時間窒化材
図 2 窒化材の組識写真 
窒化材の断面上の硬さ分布をビッカース硬さ計（測 定荷重：0.25 N) を用いて測定した結果を図 3 に示 す。縋軸は心部の硬さの平均値 $H_{v o}$ で基準化した硬さ， 横軸は表面からの距離である.なお，図には参考のた め， 9 時間および 20 時間窒化材の結果も示した。この 結果から，4 時間窒化材では表面から $25 \mu \mathrm{m}$ 程度，ま た 15 時間窒化材では $65 \mu \mathrm{m}$ まて硬さが上昇しており， これらがそれぞれの処理時間に対する窒化層深さであ る.このように, 処理時間の増加に伴って窒化層は深 くなる（図 1 参照）とともに，硬さの絶対值も增加し， より硬質の窒化層が形成されることがわかる。なお， $H_{v o}$ は処理時間にかかからず 309〜324である.

焼なまし材と窒化材の両者について，表面の粗さ測 定を行ったところ, 純チタン窒化材の場合(10) と同様 に，窒化によって表面が粗くなり，かつ処理時間の長 いほうが、より顥著であることがわかった。このよう な表面の凹凸は, 疲労強度の低下を招く要因の一つと なることが考えられる(4)(6).

3.2 疲学強度 図 4 に各処理材の $S-N$ 曲線を, また表 3 に疲労強度 $\sigma_{w}$ の値を示す。まず，末処理材の

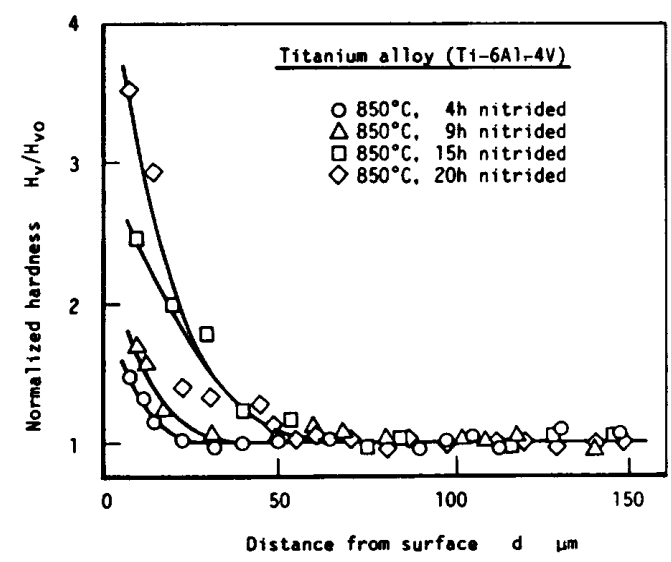

図 3 窒化材の断面上の硬さ分布

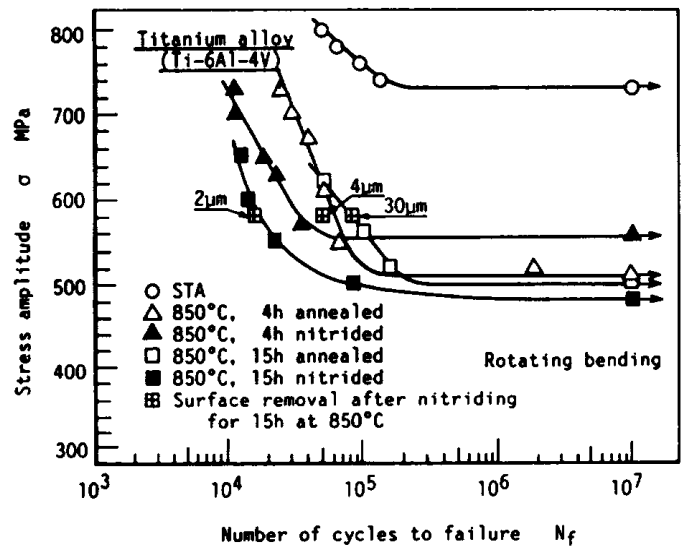

図 $4 S-N$ 曲線
場合，すなわちSTA 材および焼なまし材の結果に注 目すると, STA 材の疲労強度は焼なまし材より著し く高く，2 種類の焼なまし材はほほ同等の疲労強度を 示すことがわかる.一方, 窒化材の場合，4時間窒化材 の時間強度は焼なまし材より低下するが, 疲労限度は 逆にやや向上するのに対して，15 時間窒化材の疲労強 度は焼なまし材より低下している，さらに，両窒化材 の間では, 15 時間窒化材のほうが疲労強度は低い。す なわち，窒化層が深く，かつ硬質のほうが, 疲労強度 の低下が大きいことを示している。これまで， Ti$6 \mathrm{Al}-4 \mathrm{~V}$ 合金では, 窒化処理によって疲労強度が低下 することが報告されている(2)(4)(7)(11). 本研究結果は，処 理時間が短いときには疲労限度が改善される場合があ るが, 基本的には従来の結果とほほ同様の傾向と言え る。

図中の田印は, 15 時間窒化材について表面を雨解研 磿により徐々に除去した後, 疲労試験を行った結果て ある. 研磨量の増加に伴って, 焼なまし材の寿命に回 復していく挙動が明りょうに示されている。研磨量は $2 \mu \mathrm{m}, 4 \mu \mathrm{m}, 30 \mu \mathrm{m}$ であり，それぞれ表面にいくらか TiN 層が残存してる状態，TiN 層が完全に除去され た状態，および窒化層の約 $1 / 2$ が除去された状態に対 応している，以上のことから，TiN 層と表面近傍の硬 質の窒化廉が, 疲労強度の低下に関与していると考え られる。

3.3 疲労き裂の発生と成長誉功 STA 材を除

表 3 疲労限度

\begin{tabular}{|c|c|c|c|c|c|}
\hline \multirow[b]{2}{*}{ Treatment } & \multirow{2}{*}{ STA } & \multicolumn{2}{|c|}{$850^{\circ} \mathrm{C} \cdot 4 \mathrm{~h}$} & \multicolumn{2}{|c|}{$850^{\circ} \mathrm{C} \cdot 15 \mathrm{~h}$} \\
\hline & & annealed & nitrided & annealed & nitrided \\
\hline $\begin{array}{c}\text { Fot igue } \\
\text { limmt } \\
\sigma_{\mathrm{y}(\mathrm{MPa})}\end{array}$ & 720 & 510 & 555 & 500 & 490 \\
\hline
\end{tabular}

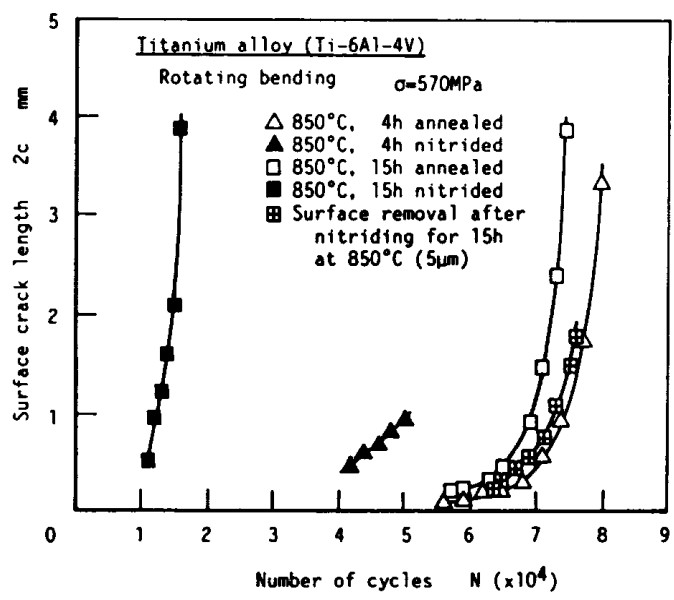

図 5 表面き裂長さと綝返し数の咸保 
く各処理材について, $\sigma=570 \mathrm{MPa}$ の応力レベルでき 裂発生，き裂形隹および成長挙動を観察した。

$3 \cdot 3 \cdot 1$ き裂発生 図 5 に表面き裂長さ $2 c$ と繰 返し数 $N$ の関係を示す.この結果から, き裂発生は 15 時間窒化材で最も早く，次いて 4 時間窒化材であり， 両焼なまし材は同程度で最も痋いことがわかる．以上 のことから，窒化処理によってき裂発生抵抗は明らか に低下し，しかもそれは処理時間の増加に伴って影著 となる。また， 15 時間窒化材の表面を龟解研磨により 約 $5 \mu \mathrm{m}$ 除去した試験片のき裂発生が，焼なまし材の 挙動とほほ同様となることから，き裂発生抵抗の低下 には，TiN 睂および表面近傍の固溶首の挙動が関係 していることがわかる. 以上のようなき裂発生挙動は, 窒化によってき裂発生抵抗が改善された純チタンの結 果(10) とは全く異なっている.

表面観察から, 窒化材では，極めて特異なき裂発生 挙動を呈することが明らかになった。典型的な場合と して, 図 5 に示した 15 時間窒化材について, き裂発生 直後の様相を図 6 に示す. 直前 $\left(N=1.0 \times 10^{4}\right)$ ではな んら発生の兆候は認められなかったにもかかわらず, わずか 1000 回の綝返し後には $2 c=498 \mu \mathrm{m}$ のき裂が 発生している。このような挙動の再現性を確認するた めに，異なる試験片についても同様の钼察を行ったと ころ $N=9 \times 10^{3}$ で $2 c=1390 \mu \mathrm{m}$ のき裂が発生した. この場合も, 直前の観察 $\left(N=8 \times 10^{3}\right)$ ではき裂は認め られなかった，後者の試験片において，き裂長さの中 央で軸方向に切断し，内部方向の様相を観察した結果 を図 7 に示す。これから明らかなように，すでにき裂 は心部に達しているが，き裂深さ $a$ は $133 \mu \mathrm{m} て ゙ あ り ，$

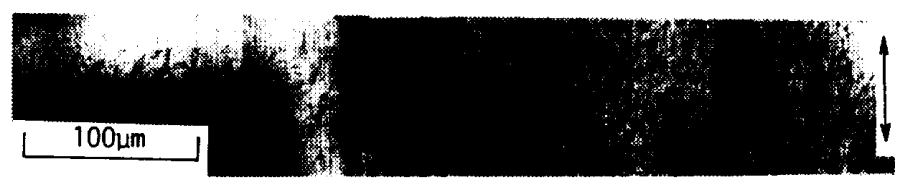

図 615 時間空化材におけるき裂発生様相 $\left(\sigma=570 \mathrm{MPa}, N=1.1 \times 10^{4}, 2 c=498 \mu \mathrm{m}\right)$ (矢印は試験片軸方向)

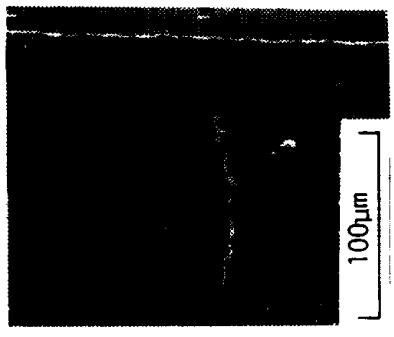

図 715 時間窒化材における試臨片内部方向のき 裂発生様相 $\left(\sigma=570 \mathrm{MPa}, N=9.0 \times 10^{3}, 2 c\right.$ $=1390 \mu \mathrm{m}, a=133 \mu \mathrm{m})$
長さに比して極めて浅い。この場合は, 1000 回の剆定 間隔の間のある期間の急速な成長を含む結果, 上述の ような寸法に達しているものと思われるが, 後述の破 面観察からも明らかなように，き裂は比較的大きな寸 法を単位として, 瞬間的に発生するか, あるいは表面 首のみを急速に成長しているものと考えられる。この ようなき裂は, 内部方向に連続的に成長し，破壤を引 き起こす主き裂となっていることから，前述したよう な早期のき裂発生が, 疲労強度低下の主たる原因であ ると考えられる。

$3 \cdot 3 \cdot 2$ 裂成長様相試験片表面におけるき裂 成長様相を図 8 に示す。焼なまし材の場合，いずれも 微細な屈曲を併って巨視的には応力軸に垂直に成辰す るが，窒化材の場合，き裂は直線状の形態を示してお り，明らかに焼なまし材とは異なっている。しかし, 15 時間空化材の TiN 層を除去した試験片のき裂は, 全 体的に直線状の形態を保ちながらも，届曲も示すよう になることから, 窒化材の直線的なき裂形態は, 表面

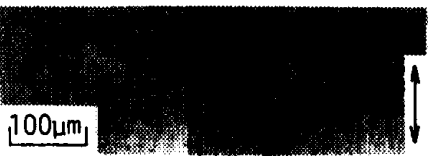

（a） 4 時間焼なまし材 $\left(N=7.1 \times 10^{4}, 2 c=548 \mu \mathrm{m}\right)$

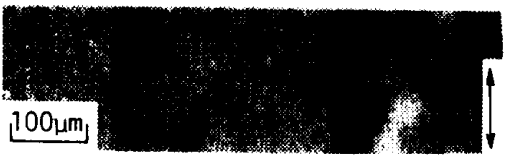

（b） 4 時間窒化材 $\left(N=4.4 \times 10^{4}, 2 c=580 \mu \mathrm{m}\right)$

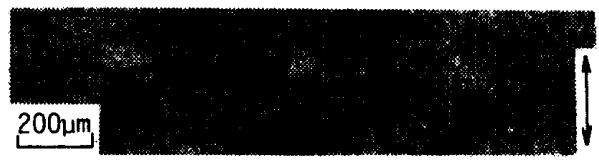

（c） 15 時間佬なまし材 $\left(N=7.1 \times 10^{4}, 2 c=1470 \mu \mathrm{m}\right)$

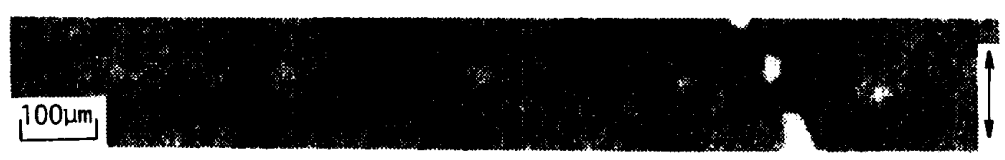

（d） 15 時間窒化材 $\left(N=1.3 \times 10^{4}, 2 c=1210 \mu \mathrm{m}\right)$

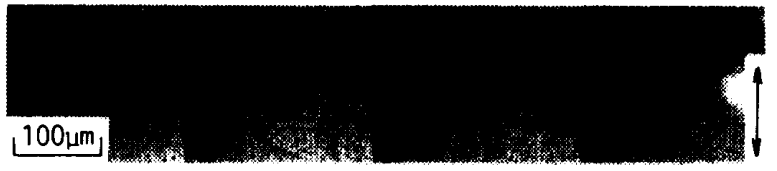

(e) 15 時間窒化材の表面 $5 \mu \mathrm{m}$ 䟻去材 $\left(N=7.1 \times 10^{4}, 2 c=765 \mu \mathrm{m}\right)$

図 8 試験片表面におけるき裂成長様相 $(\sigma=570$ $\mathrm{MPa}$ )

（矢印は試跧片軸方向） 
の TiN 眉の性筫を反映した結果であると考えられ る.なお，15 時間窒化材では，5〜6本のき裂が発生し， それぞれが独立して成長した後, そのなかの 1 本が主 き裂となるが，4 時間空化材では，多数のき裂が発生 し，ある長さ以上に成長すると合体が顕著となり，急 速に破壊に至る（図 5 参照）。

$3 \cdot 3 \cdot 3$ き裂成長速度図 9 に焼なまし材および 15 時間窒化材のアスペクト比 $a / c$ の変化を示す. 焼な まし材では, アスペクト比はき裂長さの短い領域の 0.85 程度から, き裂曼さの増加に伴い直線的にわずか に減少する傾向を示すが, 15 時間窒化材では, 前述し たように発生直後は極めて小さく，き裂長さとともに

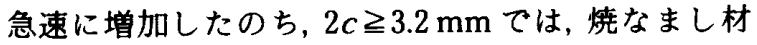
の結果と一致する。

図 9 の結果を用いて求められた表面のき裂成長速度 $d c / d N$ と表面の最大応力拡大係数 $\left(K_{\max }\right)_{c}$ の関係, お よび内部方向の成長速度 $d a / d N$ と最深点の最大応力 抎大係数 $\left(K_{\max }\right)_{A}$ の関係を図 10 に示す.ここで, 15 時 間窒化材の場合, 短いき裂に対してアスペクト比を求 めることが困難であったので, 図 9 に破線で示すよう に，その䇢囲ではき裂長さにかかわらず一定として取 扱った。また， 4 時間窒化材および 15 時間窒化材の表 面を電解研磨により除去した試験片については，それ ぞれ 15 時間窒化材および焼なまし材の結果を用いた。 なお, 応力拡大係数は白鳥ら (12) の解析結果を用いて 求めた。図より，内部方向の成長速度は，窒化材と焼な まし材との間で差異は認められないが, 窒化材の表面 の成長速度は，焼なまし材に比べて明らかに加速して おり，硬質の窒化層はき裂成長を加速させる効果を有 していることがわかる．加速の程度は $K_{\max }$ の小さい ほど，すなわちき裂長さの短いほど大きい傾向があ る. 以上の結果から, 加速の認められなかった内部方 向の成長においても，き裂深さの浅い場合，すなわち き裂発生直後は，窒化首の影䉕を相対的に大きく受け

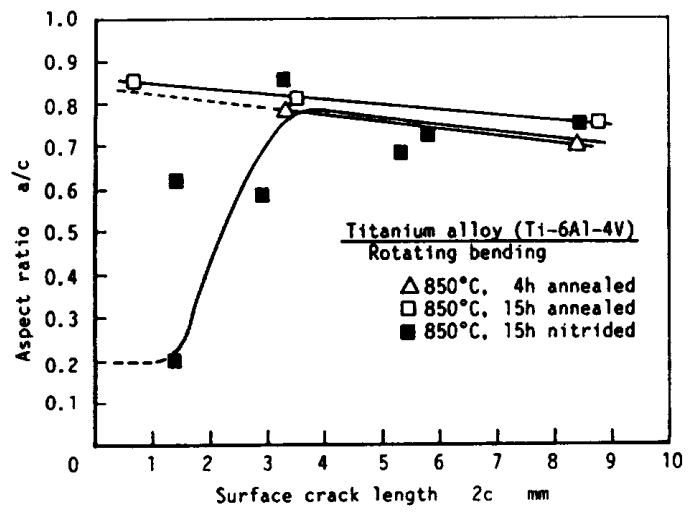

図 9 き裂長さに伴うアスペクト比の変化
るから，き裂成長の加速を生じているものと考えられ る.

3.4 破面钼家 15 時間焼なまし材および窒化材 の破面の走查形電子䫓微鏡写真を,それぞれ図 11 お よび図 12 に示す.焼なまし材では（図 11），き裂発生 点から放射状に筋模様が観察できることから，き裂は 同心円状に成長していると考えられる。一方, 窒化材 ては (図 12)，表面近傍のある長さを起点として, 内部 方向に向かって平行な（表面に対して垂直）筋模様が 認められる。同様の観察結果が，森田ら(11)によっても 得られている，彼らは，窒化材ではき裂が窒化首内を 優先的に成長した後, 内部に向かって成長するとして いるが, 発生挙動の钼察結果から,むしろ綝返しのあ る時点で比較的大きい寸法を単位として, き裂が瞬間

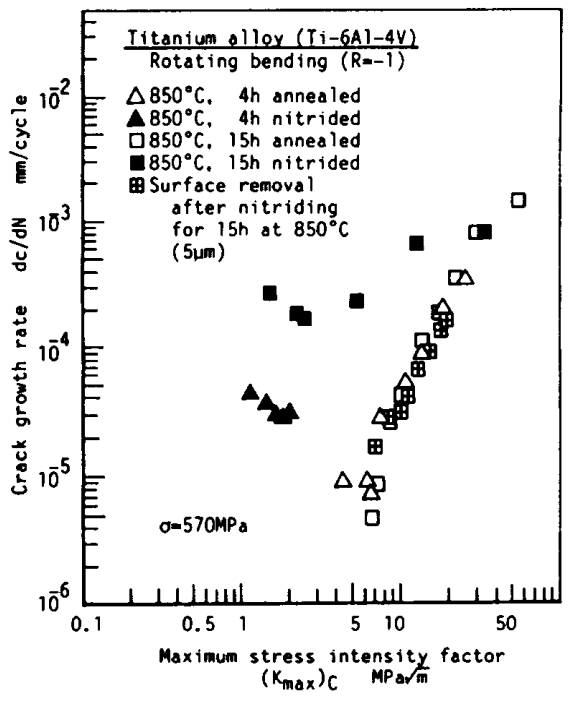

（a）陚瑀表面

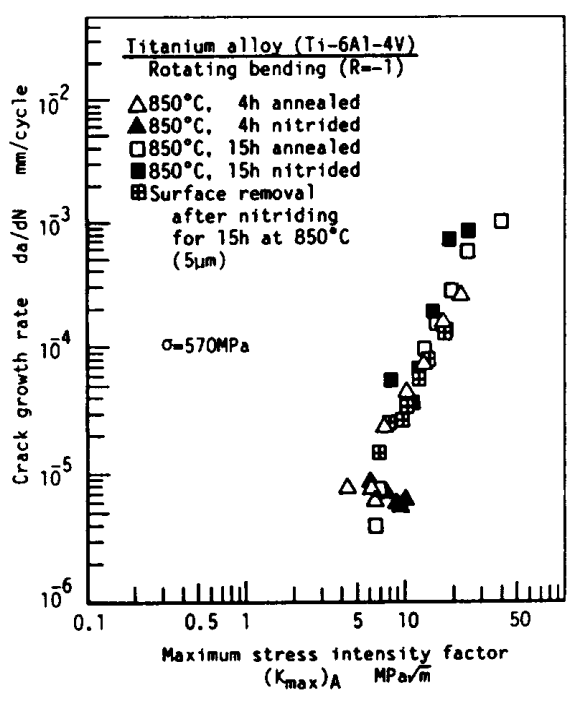

(b) 最深点

図 10 き裂成辰速度と最大応力拡大係数の関係 
的に発生するか，あるいは表面补のみを急速に成長し た後，それを起点としてき裂が内部方向に成長した結 果であると考えられる。

\section{4. 考察}

図 4 に示したように，同一熱展歴を受けた焼なまし 材と比べて，4時間空化によって疲労限度がいくらか 改善されるものの時間強度は低下し，また 15 時間窒 化では全体的に疲労強度は低下する。また，窒化時間 の増加に伴って，すなわちより硬質で深い窒化層を有 するほど疲労強度の低下は顕著となる，従来から $\mathrm{Ti}-$ $6 \mathrm{Al}-4 \mathrm{~V}$ 合金では，窒化処理によって疲労強度が低下 することが知られていた(2)(4)(7)(11). しかし，結果の多く は耐摩耗性の改善に主眼を置き, 疲労強度を付随的に 評価しているにすぎないので，その低下の原因は検討 されていないばかりか, 窒化処理によって疲労強度が 低下するといっても，比較の基準となる強度がどのよ うな条件のもとで得られているのか不明である．室化 処理は高温て，ある時間の保持を必要とするから，そ れによって組織が変化する。一般に，チタン合金の強 度は組織敏感性を示すから，窒化首の影響を検討する 場合は，同一の熱履歴を有する材料との比較が必要で ある，従来の結果のみならず，最近森田ら(11)によって 得られている極めて大きな疲労強度の低下にも，この 点が関係している可能性がある，一方，本研究や前報 の結果(10)においては，同じ熱履歴を受け，組織や結晶 粒径も全く同一の焼なまし材を比較材としているか ら，笽密に窒化の効果のみが抽出されていると考えら れる.なお，本研究の結果においても，もし窒化材の疲 労強度が本材料の標準的な熱処理のひとつである

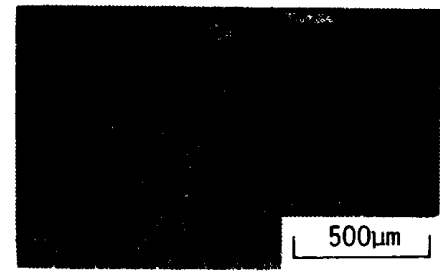

（a）破面の全体䇐相

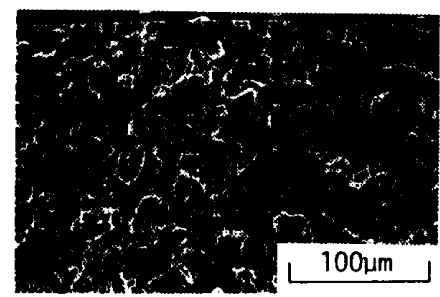

（b）き裂発生点近傍

図 1115 時間焼なまし材の破面写真
STA 材の結果と比較されれば，公化材は著しい低下 を示すことになる.

窒化材の表面を徐々に電解研磨によって除去し, 疲 労試験を行った結果から（図 4），窒化国の中でも， $\mathrm{TiN}$ 層および表面近傍の硬質の固溶層が, 疲労強度 の低下に関与していることが明らかである。加えて， 研磨によって表面を除去した試験片のき裂発生挙動が 焼なまし材と同様の挙動を示す (図 5 ) ことや, 発生直 後のき裂形状が非常に偏平である(図 7, 図 9)ことな どから, 上述の表面㞒の部分が早期の, しかも特異な き裂発生挙動に関係している。このようなき裂発生挙 動が，空化材における疲労強度の低下の主たる原因て あり，加えてき裂発生に続く初期のき裂成長の加速も 一因と考えられる。

窒化材におけるき裂発生抵抗の低下は, 主として $\mathrm{TiN}$ 層と心部との変形特性の相違に㷌すると考えら れる.チタン合金は強度が高く, 弾性係数は鋼の約 $1 / 2$ であるから，疲労試験中大きな弾性変形を伴う，一方， TiN 首の弾性係数は心部の 2 6 倍程度であると言わ れている(13)(14) から，TiN 首は敩しい変形状態を被る とともに，高い応力を受けている，疲労の進行に伴っ て, 心部の疲労変形（局所的な塑性変形）が生じると, それが引き金となり，脆性的な TiN 首およびその下 部の硬質の固溶層が急速に割れることになる。これが 窒化材て観察された特異なき裂発生形態となっている と思われる. TiN 首およびその直下の硬質の窒化層が 割れるから，発生直後のき裂形状は極めて偏平となり， それに続く内部方向のき裂成長が急速に生じて安定な き裂形状に移行することになる(図 9)。このようなき 裂発生挙動は，窒化層の性質に依存し，より硬質の窒

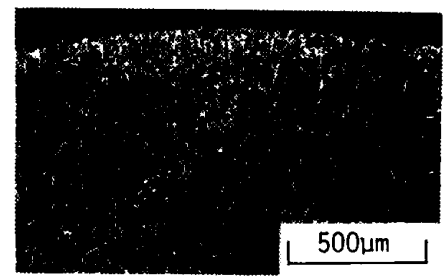

（a）破面の全体粎相

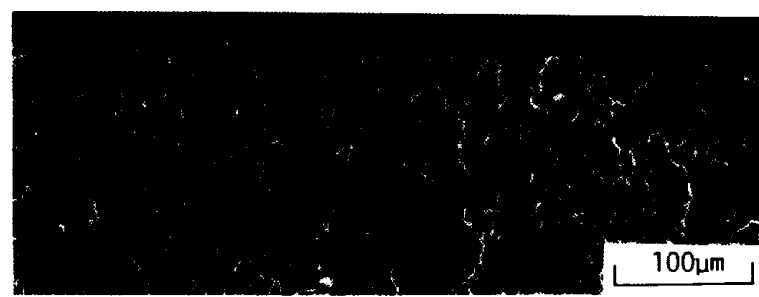

（b）巽発生点近傍

図 1215 時間窒化材の破面写真 
化眉が形成されている場合に顆著になると考えられ る.なお, 窒化材の疲労限度の応力では, $10^{7}$ 回後に, 停留き裂は観察されなかった。すなわち, 疲労限度は, 窒化層が上述のような状態に対して, き裂の発生に耐 えうる上限の応力として決まっていると考えられる。

ところで, 純チタンの場合, 窒化処理によって疲労 強度は改善され，それは窒化首によってき裂発生抵抗 が増加したことに起因していた。これは, 純チタンの 疲労強度が $\mathrm{Ti}-6 \mathrm{Al}-4 \mathrm{~V}$ 合金の約 $1 / 2$ 程度であり, 前 述した弾性変形や TiN 首の応力が小さいので, 硬質 のTiN 層や固溶首がき裂発生を抑制したためであ る。すなわち, 窒化層は，心部（母材）の強度に依存し て，き裂発生を抑制する，またはそれを助長する効果 のいずれをも有することになる.

\section{5. 結踚}

$850^{\circ} \mathrm{C} て ゙ 4$ 時間および 15 時間の窒化処理を施した $\mathrm{Ti}-6 \mathrm{Al}-4 \mathrm{~V}$ 合金について，回転曲げ疲労試験を行い， 疲労き裂発生, き裂形態, 成長挙動および破面などの 詳紐な観察から、窒化の疲労挙動に及ほす影響につい て検討した，得られた結論は，以下のとおりである。

（1）窒化層は処理時間の増加に伴い深くなり, ほ ほ 15〜20 時間で一定となる傾向がある. 窒化層深さ は，4 時間窒化材および 15 時間窒化材に対して，それ ぞれ約 $25 \mu \mathrm{m}$ および $65 \mu \mathrm{m}$ である. また, 窒化首の硬 さも処理時間に伴って上昇する。

（2） 4 時間窒化材では, 時間強度は同一熱履歴を 受けた焼なまし材より低下するが, 疲労限度はやや上 昇する。一方, 15 時間窒化材では, 時間強度および疲 労限度とも低下する。

(3) 窒化材のき裂発生は, 焼なまし材と比べて早
い.すなわち，窒化によってき裂発生抵抗は低下する。 窒化材のき裂発生形態は特異なものであり,き裂発生 は, 表面の $\mathrm{TiN}$ 居とその下部の硬質の窒化層が比較 的大きな寸法で瞬間的に割れることによって生じる。

（4）窒化材のき裂成長速度は, 試験片内部方向で は焼なまし材と同程度であるが, 空化層の影箬を直接 反映する表面では影著な加速を示し，その程度はき裂 長さの小さいほど大きい。

（5）窒化材における時間強度および疲労限度の低 下は, 主として疲労き裂発生抵抗の低下に起因してお り，加えて初期のき裂成長の加速も一因である.

最後に，本供試材は(株)神戸製鋼所より提供された ものである.記して謝意を表する。また，本研究におけ る公化処理は，岐阜県金属試験場のご協力を得た。ご 便宜をいただいた関谷祐彦場長, 松永義氏および朝 原 力氏に感謝する。.さらに，本研究を卒業研究とし て協力された岐皁大学学生の久松吾郎君に感謝する。

\section{文献}

（1）西村，金虏チタンとその応用，(1983)，275，日刊工業新 闻社.

(2) Bell, T.,ほか 4 名, Surface Eng., 2-2(1986), 133.

（3）吉田・破野，機械試䍆所所報, 10 (1956)，78.

(4) Mitchell, E. and Brotherton, P. J., J. Inst. Metals, 93 (1965), 381.

（5）中野・ほか3名，金属誌，24-8(1960)，500.

（6）高村, 金属誌, 24-9(1960), 565 .

( 7 ) Mordika, B. L. and Bergman H.W., Mat. Res. Soc. Symp. Proc., 58(1986), 335.

(8) 新行内, 工業材料, 33-12(1985)， 72.

(9) Vardiman, R. G.,ほか2 名, Rept. NRL Prog., (1979-5), 4.

（10）戸梶・ほか 2 名，機論，57-534，A(1991)，268.

(11) 森田・ほか 3 名, 機論, 56-529, A(1990), 1915.

（12）白鳥・ほか 3 名, 機論, 53-488, A (1987)， 779.

（13）罒本・ほか 2 名，金属誌，50-3(1986)，320.

（14）水田・河本，セラミック材料，(1986)，38, 東京大学出版会. 